\title{
Physical defence of the wild cucumber Echinocystis lobata in an invasive range changing seed removal by rodents
}

\author{
Lukasz Dylewski • Lukasz Maćkowiak • Lukasz Myczko $\mathbb{D}$
}

Received: 6 February 2018/Accepted: 16 May 2018/Published online: 25 May 2018

(C) The Author(s) 2018

\begin{abstract}
Invasive alien plant species in a new location usually lose their native enemies, but new interactions with local herbivores can also significantly influence their population dynamics. Seed predators have a strong effect on the seed banks, seedling recruitment, and establishment of a plant population. A given plant's effective defence of its seeds from seed predators ensures its survival. Here, we describe a new kind of physical protection in the wild cucumber (Echinocystis lobata) in its invasive range: the production, in the central part of the fruit's fibre frame, of 1 or 2 additional seeds which cannot be released. Research was conducted in riparian habitats
\end{abstract}

Communicated by Martin Nunez.

Electronic supplementary material The online version of this article (https://doi.org/10.1007/s11258-018-0842-2) contains supplementary material, which is available to authorized users.

Ł. Dylewski · Ł. Myczko ( $\bowtie)$

Institute of Zoology, Poznań University of Life Sciences, Wojska Polskiego 71C, 60-625 Poznan, Poland

e-mail: lukasz.myczko@up.poznan.pl

Ł. Dylewski

e-mail: dylewski91@gmail.com

Ł. Maćkowiak

Department of Grassland and Natural Landscape

Sciences, Poznań University of Life Sciences, Dojazd 11,

60-632 Poznan, Poland

e-mail: lukaszmackowiak123@gmail.com in the central part of Poland. After performing three different studies to examine this phenomenon, we found that, on average, $34 \%$ of individual wild cucumber fruits contained additional trapped seeds which could not be released. Our results showed that trapped seeds have the same ability to germinate as normally released seeds, but that they differ from normal seeds in weight and shape. The frequency of removal of trapped seeds by rodents was significantly lower than that of normally released seeds. This mechanism is likely to change seed distribution in the wild cucumber's environment.

Keywords Wild cucumber Echinocystis lobata . Trapped seed · Post-introduction · Seed removal · Seed protection $\cdot$ Novel physical defences

\section{Introduction}

The successful protection of seeds against predation is a key challenge in the life cycle of most plant species (Janzen 1971; Hulme 1996). Loss of developed seeds is a substantial cause of mortality in plants (Nathan and Casagrandi 2004). Seed predators have an important impact on seed survival, and thus affect plant population dynamics and community structure (Janzen 1970; van Klinken and White 2014; Yu et al. 2014). New adaptation protecting seeds against seed 
predators and enhancing the probability of their successful germination should be positively selected. Plants have developed a variety of defence mechanisms, both physical and chemical, to prevent seeds from being consumed both before and after dispersal (Barclay 2015). The most common defence strategy against seed predators is produce dry fruits (e.g. capsules, follicles, legumes, nuts), which may be characterised by thick and woody walls as well as by the presence of spines, bristles, or irritant hairs (Hulme and Benkman 2002). As well, in fleshy-fruit species, a fibrous seed coat often physically protects seeds (Hulme and Benkman 2002). Seeds, especially in arid areas, may have a mucilaginous seed coat that can glue soil to the seed, thus hiding it from granivores (Fuller and Hay 1983). Other adaptations, such as the production of cryptic and mimetic seeds (Nystrand and Granström 1997; Brancalion et al. 2010; Porter 2013; Lev-Yadun 2016) or of empty seeds (Perea et al. 2013; Myczko et al. 2015), influence seed survival in natural conditions.

For many plant species, rodents are the most important post-dispersal seed predators, with a significant negative effect on seed banks, seedling recruitment, and establishment of plant regeneration patterns (Nuñez et al. 2008; Pearson et al. 2014; Zwolak et al. 2016). Moreover, small mammals may notably affect the structure of populations and the incidence of plant species in many ecosystems (van Klinken and White 2014; Yu et al. 2014).

Success of invasion, due to local assembly theory, depends on local community filters and on alien plant species-if it behaves like native or it shows novel, outperforming community interactions in new range (Pearson et al. 2018). We can expect alien plant species moving into new areas to evolve differently compared with the same species within their native range, due to different selection and inheritance resulting in adaptation (Müller-Schärer et al. 2004; Blair and Wolfe 2004). The novel conditions encountered by these plants in their invasive range probably contribute to the creation of novel mechanisms through altered selection influenced by new biotic and abiotic factors (Richards et al. 2006; Yoshida et al. 2007; Prentis et al. 2008).

Previous studies provide that native generalist seed predators represent a significant source of biotic filter to invasion plant (Vilà and Gimeno 2003; Nuñez et al. 2008; Blaney and Kotanen 2001; Perukschas et al.
2014; Pearson et al. 2012). Many introduced plants require seed for establishment and persistence in the new range (Pearson et al. 2012). Seed predation is one of the important filters, which has a negative effect on non-native plants by depressing seed production (Bogdziewicz et al. 2017; Myczko et al. 2017), recruitment establishment (Pearson et al. 2012; Maron et al. 2012), and adult plant population densities (Pearson et al. 2012). However, seed size (Connolly et al. 2014), novel seed chemical compounds (Pearson et al. 2011), habitat type (Connolly et al. 2014), abundance, and difference species of consumers (Reader 1993; Carrillo-Gavilán et al. 2010) could influence on propagule pressure which is important for the success or failure of these plants in new range.

According to the novel weapons hypothesis, novel chemical defences, may possess explaining success of invaders in an second range (Callaway and Ridenour 2004) and might release from natural enemies (Pearson et al. 2011). However, it is also possible for an invader to present novel physical defences to promote seed survival. In this study, we present a previously unreported post-introduction phenotypic shift which modifies seed removal by rodents.

The wild cucumber produces four released seeds (hereafter 'normal seeds'). Most seeds fall out immediately following the opening of the apex, though some normal seeds fall out gradually while the fruits are drying and decaying, a process which is reported as delayed seed release by Silvertown (1985) in the natural range and which is also present in the invasive range. However, apart from this, in the course of our research we observed the common phenomenon of 1-2 additional seeds, found in the central part of the fruit's fibre frame, which cannot be released from the fruit (Figs. 1, 2). We will use the term 'trapped seeds' to describe seeds of this type. Normal seeds fill the most part of the fruit chamber, therefore trapped seeds seem to be additional. We suspect, that it can influence the size and weight of trapped seeds. Moreover, trapped seeds are fully developed so it should not influence the germination abilities. We also observed that wild cucumber individuals can produce single fruits with three seed chambers. This kind of fruit releases six normal seeds after the opening of the apex and pores.

Here, we test the following hypotheses: (1) trapped seeds differ in size and weight from normally released seeds from the same individual; (2) trapped seeds 


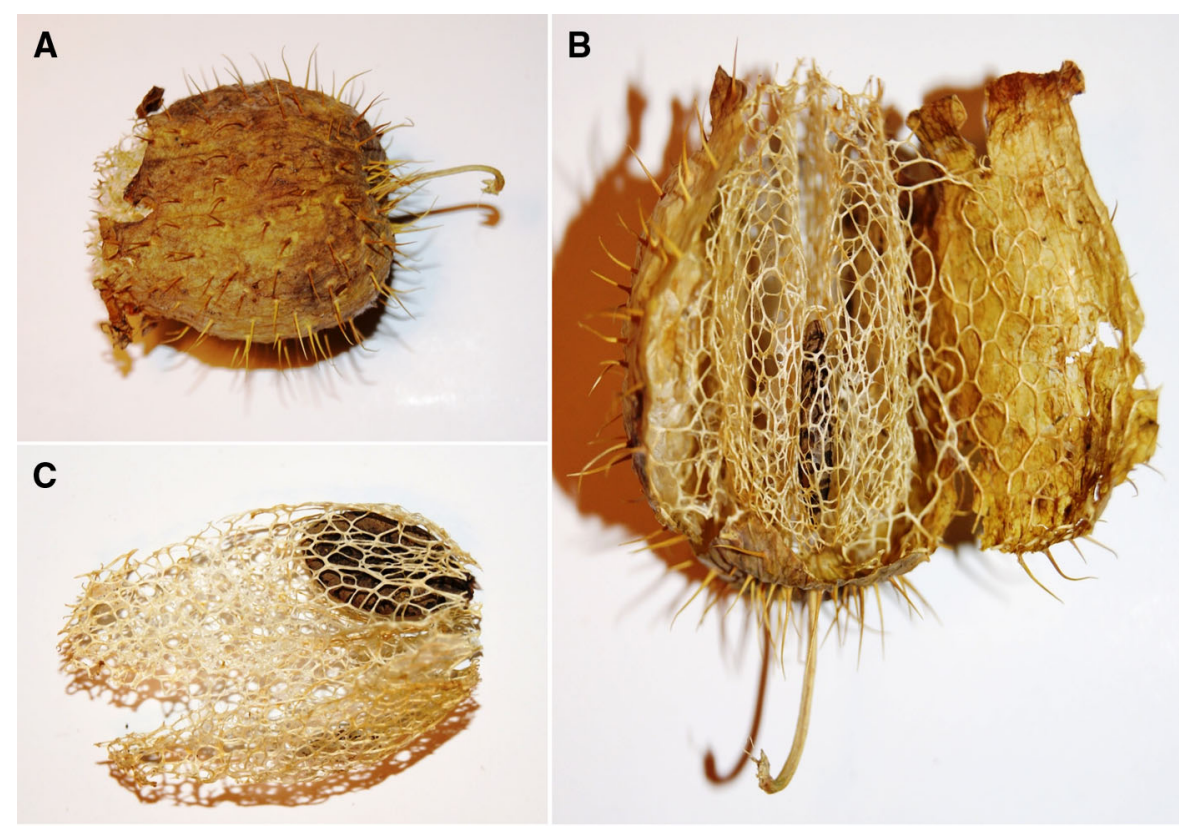

Fig. 1 The wild cucumber (Echinocystis lobata) fruits. a dried fruit, $\mathbf{b}$ and $\mathbf{c}$ the internal fruit frame with trapped seed

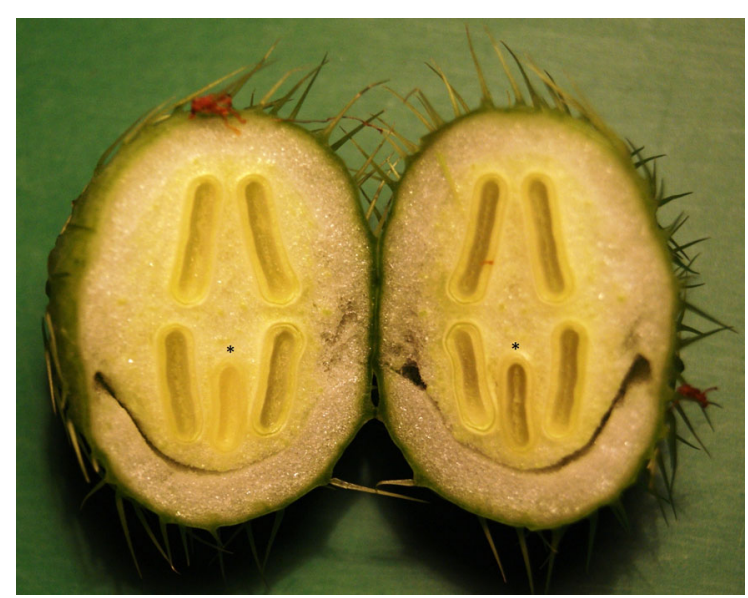

Fig. 2 Cross-section through fruit with 4 normal seeds and one trapped seed (asterisk marked)

possess the same ability to germinate and emerge as normally released seeds; and (3) trapped seeds in fruit tissues are characterised by a lower predation level than normally released seeds.

\section{Materials and methods}

\section{Study design}

To determine the frequency of the occurrence of trapped seeds, we collected all fruits from 23 wild cucumber specimens growing in riparian habitats, randomly selected from 23 different locations (one specimen from each location) in the central part of the Wielkopolska region of Poland $\left(52^{\circ} 20^{\prime} \mathrm{N}, 16^{\circ} 31^{\prime} \mathrm{E}\right)$. In total, 1584 fruits were collected. The specimen in each location was randomly selected. The minimum distance between neighbouring sample locations was set at $1 \mathrm{~km}$ in order to avoid the influence of local environmental factors on the frequency of occurrence of fruits with trapped seeds. The collected fruits were transported to the laboratory in separate containers, then kept in open containers at room temperature so that they could open and release their seeds. Subsequently, we checked each fruit for the presence of trapped seeds, noting their number and recording the number of chambers in the fruit. After being extracted from the tissues of fruits, both normal and trapped seeds were kept at room temperature for $48 \mathrm{~h}$ in order to dry them before measuring and weighing them. 
Study species

The wild cucumber (Echinocystis lobata) is native to North America, distributed mostly in the eastern parts of the continent, where it is associated with river valleys, areas surrounding ponds and lakes, and riparian forests (Foster and Duke 1990). This species was introduced to Europe at the end of the nineteenth and the beginning of the twentieth century as an ornamental plant. The wild cucumber spread from gardens to natural habitats, and nowadays occupies an ecological niche in Europe similar to that associated with its natural range, where it is a component of riparian communities, e.g. rushes, riparian forests, and nitrophilous communities. In Europe, the wild cucumber is an invasive species, listed as one of the 100 most dangerous alien species threatening natural ecosystems (Nentwig 2009). The wild cucumber is an annual plant, classified among competitive-ruderals, i.e. it occurs in highly productive habitats in which the dominance of vegetation by competitors has been prevented by some disturbance (Grime 1979). Compared to native plant species occurring in these riparian communities, the wild cucumber offers local seed predators large seeds with great amounts of energy. These seeds are larger than those of native species such as hedge bindweed (Calystegia sepium), the seeds of which contain calystegines, compounds which can be toxic to animals (Schimming et al. 2005). Thus, local seed predators are expected to include wild cucumber seeds in their diets as a rich new source of food.

The wild cucumber is an annual vine in the family Cucurbitaceae. Fruits grow to lengths of $2.5-5.0 \mathrm{~cm}$ and widths of $2.5-3.5 \mathrm{~cm}$ and are covered by prickles. In most cases, the fruits are suspended from the stem of the plant and hang from the distal end. The apex of the pepo (fruit) is peeled back, with 5 or 6 wide flaps revealing 2 oval pores through which seeds are expelled (Silvertown 1985). Each fruit contains 1-6 released seeds, but 4 is the most common number (Silvertown 1985). Seeds are released from fruits irregularly. A number of seeds fall just after the fruit opens, the rest after the fruit dries. The seeds of the wild cucumber are flat and smooth, with a dull surface featuring brownish or dark brown markings (Silvertown 1985; Flora of North America Editorial Committee 2015).
Seed biometrics

Normal and trapped seeds from each specimen were scanned (HP Deskjet F4280). Subsequently, using scanned images of seeds, we measured their size $\left(\mathrm{mm}^{2}\right)$, perimeter $(\mathrm{mm})$, length $(\mathrm{mm})$, width $(\mathrm{mm})$, ratio of length to width, and degree of circularity. To perform this analysis, we used SmartGrain software (Version 1.1). Additionally, each seed was weighed to an accuracy of $\pm 0.01 \mathrm{~g}$.

\section{Germination experiment design}

We established experimental plots within areas where the occurrence of wild cucumber plants had been previously documented. The experiment was conducted in patches of the kind of habitat this plant prefers. We created six plots with a minimal reciprocal distance of $50 \mathrm{~m}$. Each plot measured $4 \times 4 \mathrm{~m}$. We placed 60 seeds, i.e. 30 normal and 30 trapped seeds inside dried fruits, in each plot. Seeds were placed alternately. The distance between seeds was roughly the same. The plots were protected by wire (mesh size $10 \mathrm{~mm}$ ) to prevent the potential removal of seeds. The experiment started in April. We visited the study plots at 2-week intervals and made a separate note of the number of established seedlings from normal and trapped seeds. We carried out three visits at regular intervals. Following the end of the experiment, we destroyed all seedlings and other seeds which did not germinate.

\section{Seed removal experiment design}

Before attempting the main experiment, we conducted a primary study in Uścikowiec $\left(52^{\circ} 39^{\prime} \mathrm{N}, 16^{\circ} 48^{\prime} \mathrm{E}\right)$ in which we established 3 trays, each with 15 normal seeds and 3 fruits containing trapped seeds. Thus a total of 18 seeds were placed on each tray. The distance between the trays during the primary study was $20 \mathrm{~m}$ (in the experiment, this distance was increased to $100 \mathrm{~m}$ ). A camera trap (Bushnell NatureView HD Live View model no. 119740) was placed next to each tray. All 3 trays were placed in the immediate vicinity of seed-releasing wild cucumber individuals. The main field experiments were conducted in October and November 2016 in 4 research areas: Noteć $1\left(53^{\circ} 03^{\prime} \mathrm{N}, 16^{\circ} 52^{\prime} \mathrm{E}\right)$, Noteć $2\left(53^{\circ} 01^{\prime} \mathrm{N}\right.$, $\left.16^{\circ} 54^{\prime} \mathrm{E}\right)$, Kanał Grabarski $1\left(52^{\circ} 10^{\prime} \mathrm{N}, 16^{\circ} 28^{\prime} \mathrm{E}\right)$, and 
Kanał Grabarski $2\left(52^{\circ} 08^{\prime} \mathrm{N}, 16^{\circ} 28^{\prime} \mathrm{E}\right)$. We placed 10 trays in each research area in the immediate vicinity of seed-releasing wild cucumber individuals. On each tray, we placed 6 normal seeds and 3 fruits with trapped seeds. Thus, a total of 9 seeds were placed on each tray. The minimum distance between the trays was $100 \mathrm{~m}$, in order to minimise the risk of the same rodent visiting neighbouring trays. The shortest distance between trays in the Noteć research areas was $3.4 \mathrm{~km}$ and in the Kanał Grabarski research areas, $2.5 \mathrm{~km}$. The distance between the Noteć and Kanat Grabarski research areas was $96 \mathrm{~km}$. All research areas were characterised by typical riparian vegetation with large numbers of wild cucumber individuals. We covered the trays with mesh wire to protect fruits and seeds against removal by birds. In the Noteć research areas, we used normal fruits which release all their seeds, manipulated by placing one seed on each fruit with a tweezer inside a fibre flame net. In the Kanat Grabarski research areas, we used collected fruits with one trapped seed inside each fruit. During the experiment, we used nitrile gloves to reduce additional odours that might affect rodents' behaviour. To detect the presence of small rodent species in the research areas, following the end of the experiments we established two live traps (TRIXIE TX-4192, $5 \times 5 \times 17 \mathrm{~cm})$ at the site of each tray. We trapped rodents for $24 \mathrm{~h}$ on each experimental surface, using wild cucumber seeds in each live trap as bait. Additionally, during the experiment, we placed one camera trap next to the tray with wild cucumber seeds at each research area.

\section{Statistical analysis}

We used the Wilcoxon test to compare the biometric features of normal and trapped seeds.

We performed a comparative analysis of the features of seeds in an ordination space using principal correspondence analysis (PCA). Chi-square independence tests were used to compare the number of germinated seedlings between normal and trapped seeds. We used survival analysis to examine the changes in the number of non-germinating wild cucumber seeds (McNair et al. 2012). To determine the seed type (normal and trapped) effect on seed germination, we used Cox's proportional hazards model (Cox 1972). We used the Mann-Whitney test to compare the intensity of seed removal between normal and trapped seeds and of seed removal from fruits with trapped seeds between the Noteć and Kanał Grabarski areas. We decided to join the data sets Noteć 1 and 2 as Noteć and Kanał Grabarski 1 and 2 as Kanał Grabarski to eliminate autocorrelation. All analysis and graphs were carried out with $\mathrm{R}$ version 3.2.3 software (R Core Team 2015), Canoco 5 for Windows (Šmilauer and Lepš 2014), and IBM SPSS 21 for Windows.

\section{Results}

Fruit and seed biometrics results

We found at least 1 trapped seed in the fruits of 21 of 23 collected wild cucumber individuals.

The share of fruits with trapped seeds in the chamber was $34 \%(n=1584$, $\min -\max 5-83 \%)$. Fruits which contained 1 additional trapped seed made up $82 \%$ of the total, those with 2 trapped seeds $17 \%$, and those with 3 trapped seeds only $1 \%$. We also observed that 57 fruits $(3.6 \%)$ contained three seed chambers with six seeds which were expelled normally.

In comparing the weight and biometric features of the two seed types, we found significant differences. We observed, based on PCA, that the features best fitted to the first axis were size area and perimeter, to the second axis length-width ratio, due to the fact that the normal group of seeds differed from the trapped seeds (Fig. 3). Trapped seeds characterised a smaller size and lower weight compare to normal seeds (Table 1).

Additionally, we observed trapped seeds in each wild cucumber population checked in autumn 2016. The locations of the checked populations were as follows: Wełna $\left(52^{\circ} 43^{\prime} 40^{\prime \prime} \mathrm{N}, 16^{\circ} 54^{\prime} 42^{\prime \prime} \mathrm{E}\right)$, Kleczew $\left(51^{\circ} 22^{\prime} 36^{\prime \prime} \mathrm{N}, \quad 18^{\circ} 10^{\prime} 21^{\prime \prime} \mathrm{E}\right)$, Dąbcze $\left(51^{\circ} 48^{\prime} 29^{\prime \prime} \mathrm{N}\right.$, $\left.16^{\circ} 39^{\prime} 32^{\prime \prime} \mathrm{E}\right)$, Trzek $\left(52^{\circ} 21^{\prime} 23^{\prime \prime} \mathrm{N}, \quad 17^{\circ} 10^{\prime} 20^{\prime \prime} \mathrm{E}\right)$, Włoszczowa $\left(50^{\circ} 51^{\prime} 17^{\prime \prime} \mathrm{N}, 19^{\circ} 58^{\prime} 00^{\prime \prime} \mathrm{E}\right)$, Odolanów $\left(51^{\circ} 34^{\prime} 09^{\prime \prime} \mathrm{N}, \quad 17^{\circ} 42^{\prime} 00^{\prime \prime} \mathrm{E}\right)$, and Łaszczów $\left(50^{\circ} 32^{\prime} 17^{\prime \prime} \mathrm{N}, 23^{\circ} 42^{\prime} 57^{\prime \prime} \mathrm{E}\right)$, as well as in the research area (Uścikówiec, Noteć, and Kanał Grabarski; see supplemental map Fig. S1). 


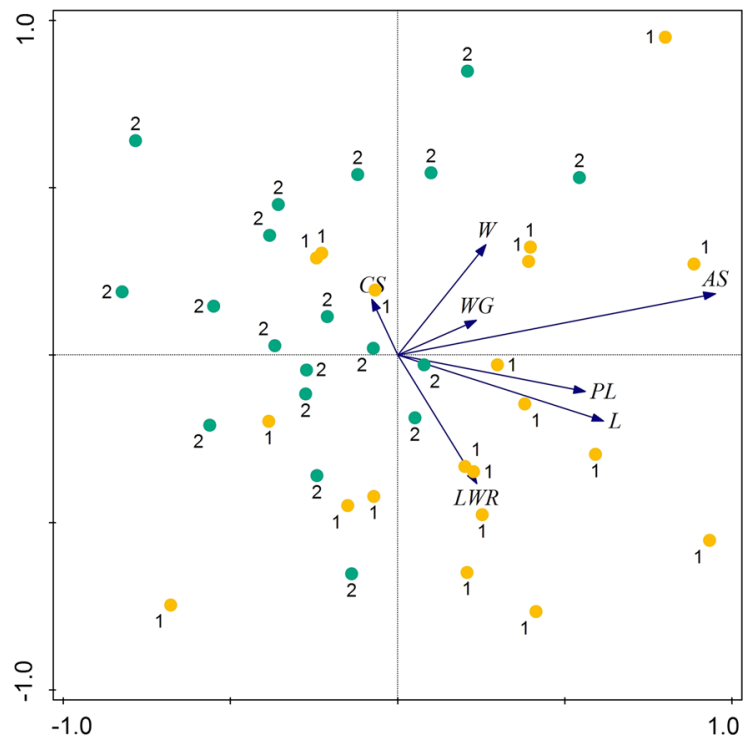

Fig. 3 Principal component analysis (PCA) of biometric features of wild cucumber (Echinocystis lobata) seeds. Eigenvalues for axis $1=0.8084$. and axis $2=0.1716$. Legend: 1 normal seed, 2 trapped seed, $C S$ Circularity, $W$ width, $W G$ weight, $A S$ area size, $P L$ perimeter length, $L$ length, $L W R$ length-width ratio

\section{Germination experiment results}

The number of germinated seeds did not differ significantly between the types of seeds $\left(\chi^{2}=1.029\right.$, $p=0.31$ ). The share of normal germinated seeds was $76 \%$ and of trapped seeds $80 \%$. The Cox's proportional hazard including seed type as a factor was not significant $\left(\chi^{2}=2.155, \mathrm{df}=1, p=0.142\right)$. The visualisation of cumulative probability for non-

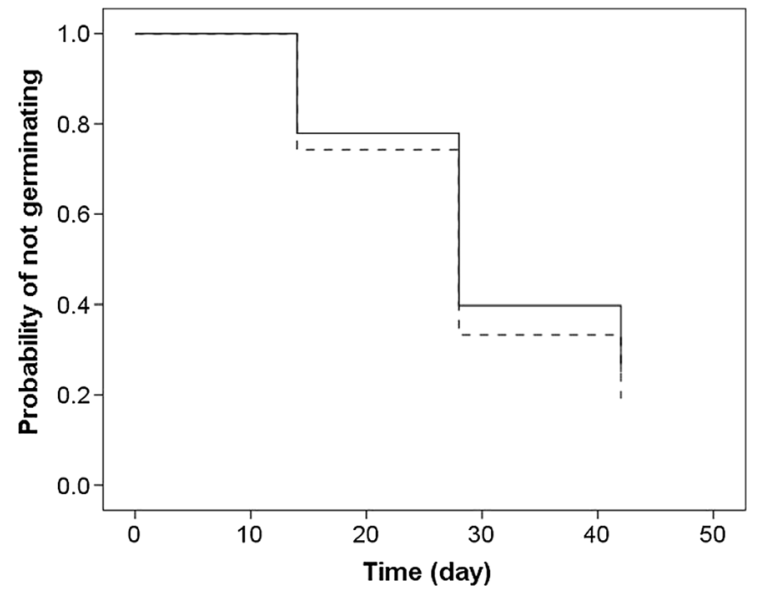

Fig. 4 Differences in probability (survival curves) for nongerminating wild cucumber seeds between normal seeds type (solid line) and trapped seeds type (dotted line)

germinating wild cucumber seeds is shown in Fig. 4. In Fig. 5, we show a germinated seedling trapped in a fruit.

Seed removal experiment results

In the case of the pilot studies in Uścikówiec, all unprotected seeds were removed within $24 \mathrm{~h}$, and all of the trapped seeds protected by fruits remained on the trays. Unsuccessful attempts to remove the trapped seeds from the fruits are visible on the video recordings from the camera traps (see supplementary materials, videos 1 and 2).

During the main experiment in both the Noteć and Kanał Grabarski research areas, all of the normal seeds were removed within 24 h. On the Noteć plots, where

Table 1 Mean, standard deviation, 95\% confidence intervals $(95 \% \mathrm{CI})$, coefficient of variation $(\mathrm{CV})$, and $Z$ test results of the biometric features on normal and trapped seed of Wild cucumber (Echinocystis lobata)

\begin{tabular}{|c|c|c|c|c|c|c|}
\hline \multirow[t]{2}{*}{ Biometric features } & \multicolumn{2}{|c|}{ Normal seed $(n=2288)$} & \multicolumn{2}{|c|}{ Trapped seed $(n=505)$} & \multirow[t]{2}{*}{$Z$ value } & \multirow[t]{2}{*}{$P$} \\
\hline & Mean (SE) & $95 \% \mathrm{CI}$ & Mean (SE) & $95 \% \mathrm{CI}$ & & \\
\hline Area size $\left(\mathrm{mm}^{2}\right)$ & $97.30(0.36)$ & $96.61-98.0$ & $85.98(0.68)$ & $84.64-87.33$ & -3.285 & 0.001 \\
\hline Perimeter (mm) & $42.86(0.09)$ & $42.68-43.04$ & $38.97(0.17)$ & $38.63-39.31$ & -3.248 & 0.001 \\
\hline Length (mm) & $16.82(0.04)$ & $16.75-16.9$ & $14.92(0.08)$ & $14.77-15.07$ & -3.845 & $<0.001$ \\
\hline Width (mm) & $8.02(0.02)$ & $7.99-8.05$ & $7.96(0.03)$ & $7.9-8.02$ & -2.053 & 0.040 \\
\hline Length-to-width ratio & $2.11(0.00)$ & $2.10-2.11$ & $1.88(0.01)$ & $1.86-1.90$ & -3.920 & $<0.001$ \\
\hline Circularity & $0.67(0.00)$ & $0.66-0.67$ & $0.71(0.00)$ & $0.71-0.72$ & -3.509 & $<0.001$ \\
\hline Weight $(\mathrm{g})$ & $0.33(0.00)$ & $0.33-0.34$ & $0.30(0.00)$ & $0.30-0.31$ & -2.352 & 0.019 \\
\hline
\end{tabular}




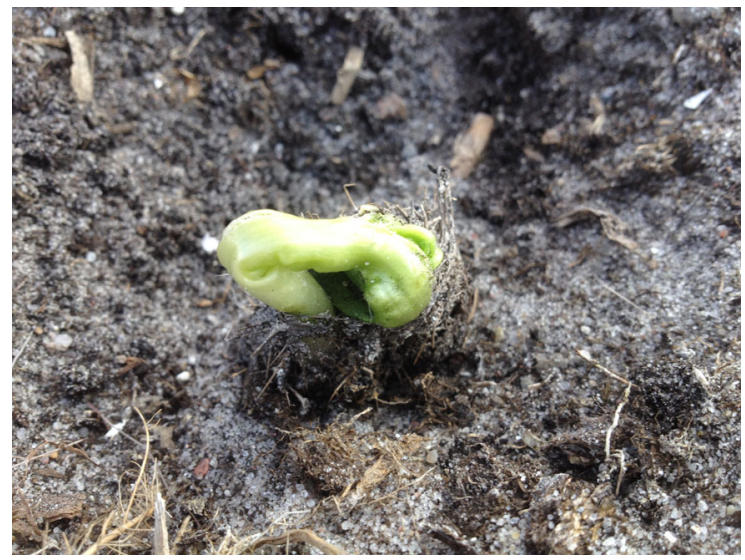

Fig. 5 Seedling germinated from trapped seed in the fruit

manipulated fruits were used, the percentage of removed seeds protected by fruits was mean $\pm \mathrm{SE}$ $60.0 \pm 6.67$ (95\% CI 46.05-73.95). The difference between the removal of normal and trapped seeds on trays in the Noteć area was significant (MannWhitney test: $Z=-4.940, p<0.001$, Fig. 6). In the Kanał Grabarski research areas, where we used collected fruits with one trapped seed inside each fruit, the percentage of removed seeds was mean \pm SE $38.3 \pm 8.81$ (95\% CI 19.89-56.77). As in the previous case, the difference in the removal of the two types of seeds from trays in the Kanał Grabarski plots was significant (Mann-Whitney test: $Z=-4.425$, $p<0.001$, Fig. 7). The differences in seed removal between manipulated fruits in the Notec areas and typical fruits with trapped seeds in the Kanał Grabarski research areas were insignificant (Mann-

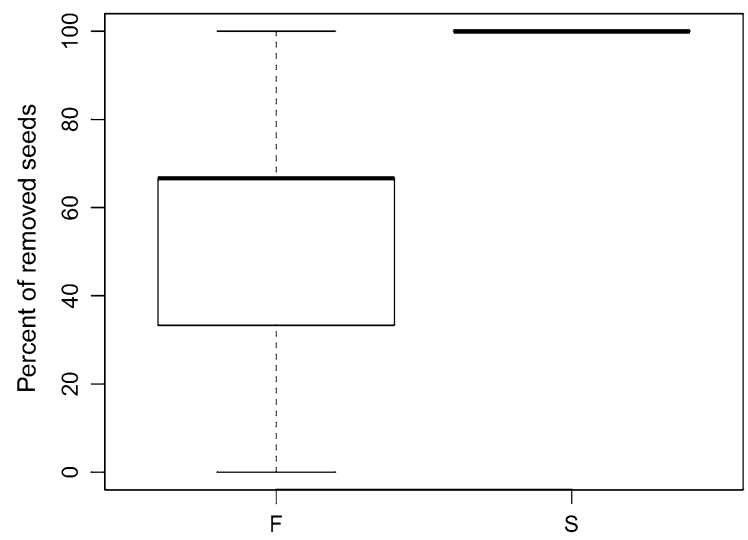

Fig. 6 Seed removal in wild cucumber by rodent between fruits with manually put seed (F) and normal seeds (S) in Noteć areas

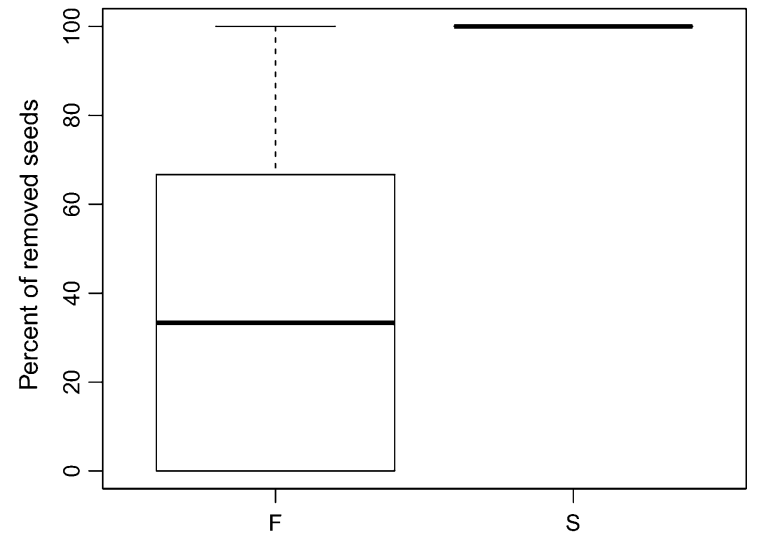

Fig. 7 Seed removal in wild cucumber by rodent between typical fruits with trapped seed (F) and normal seed (S) in Kanał Grabarski areas

Whitney test: $Z=-1.878, p=0.072$ ). The small mammals community captured in the two study areas is shown in supplementary material (Table S1).

\section{Discussion}

We described previously an unreported physical defence of the wild cucumber in its invasive range which modifies seed removal by native rodents. The phenomenon involves the occurrence of trapped seeds inside its fruit which cannot be released. We have proved, based on our seed removal experiment, that this seemingly pathological situation can significantly modify the probability of seed removal, which in turn can influence seed distribution and survival, as it is highly correlated with a reduction in seed predation (Pearson et al. 2014; Guiden and Orrock 2017). Seed survival and seedling establishment are critical stages determining an invader's success (Pearson et al. 2014; Perukschas et al. 2014; Connolly et al. 2014). A recent study demonstrated the negative impact of native consumers on non-native plants, depressing seed production, recruitment, growth, and survival (Reader 1993; Maron and Vilà 2001; Lambrinos 2006; Pearson et al. 2011, 2012). The emergence of new food sources in the form of green parts of plants, fruits, and seeds of non-native plants affects the feeding behaviour of many generalist herbivores and seed predators (Ortega et al. 2014; Aslan and Rejmánek 2016), and expands their feeding niches (Pearson et al. 2014; Myczko et al. 2014, 2017; Schilthuizen et al. 2016; Bogdziewicz 
et al. 2017). These novel antagonistic interactions contribute to biotic resistance whereby resident enemies begin targeting introduced species and provide a type of biofilter (Reader 1993; Vilà and Gimero 2003; Blaney and Kotanen 2001; Nuñez et al. 2008; Pearson et al. 2012; Perukschas et al. 2014).

In most cases, in the fruits containing trapped seeds, there was only one fully developed trapped seed in the fruit. This situation should be optimal, because it eliminates problems involving competition between directly adjacent seedlings and plants. Competition between seedlings leads to a greater reduction in the number of recruits and their fitness (Jinks and Mason 1998; Harms et al. 2000; Lambers et al. 2002). Therefore, an increase in the number of trapped seeds in one fruit probably would be not optimally beneficial; however, we found that $18 \%$ of fruits with trapped seeds contain more than one. Moreover, there is an important trade-off between the number of smaller seeds in fibrous mesh and rodent foraging selection. The less preferences of trapped seeds by rodents could be a result with size of the seed type and rodents decision to attempt to access these seeds from fibrous mesh. Trapped seeds are smaller and lighter than normal seeds; therefore, investment time to access this seed is unprofitable. Rodents tend to select large seeds (Reader 1993; Hulme 1998b), which provides a higher energy content (Jakobsson and Eriksson 2000; Henery and Westoby 2001). Combination of protective fibrous mesh, lower seed number, and reduction of seed size ensure that trapped seed are less preferred by post-dispersal seed predators.

The study results also show that wild cucumber seeds, which are relatively large, are collected very willingly and quickly by rodents occurring in the invasive range of this species. This should be expected, based on published research on postdispersal seed predation, which suggests that predators selectively prefer large seeds which provide them with greater doses of energy (Alcántara et al. 2000; Xiao et al. 2005). Nuñez et al. (2008) showed that native post-dispersal seed predators more often prefer the seeds of non-native conifers because their seeds are larger than those of native species. The native flora in the study area lacks herbaceous plants characterised by comparable seed mass. Only native deciduous tree species (e.g. beech Fagus sylvatica and oaks Quercus sp.), which normally do not occur in riparian habitats, produce seeds comparable to or even heavier than those of the wild cucumber. Native plant species commonly co-occurring with wild cucumber, e.g. Calystegia sepium and Humulus lupulus, are characterised by small seeds (24.94 and $2.50 \mathrm{mg}$, respectively) with a much lower expected energy value.

Normal wild cucumber seeds are released near parent plants. This strategy leads to an increased probability of predation (Janzen 1970; Peres et al. 1997; Hulme 1998a). In the case of plants producing small or very small seeds, a sufficient number of seeds may be expected to remain at the site, enabling selfreplacement. In the case of plants such as the wild cucumber, which produces relatively few large seeds, this process cannot be very effective without additional protection for the seeds. The strategy of producing trapped seeds can exclude a portion of produced seeds from the standard cycle of seed dispersal and predation, enabling the preservation of a practically undispersed reserve of seeds for the following growing season. This is especially likely in this case, because the morphology of this plant species provides for limited dispersal. Because the wild cucumber produces long shoots, usually several metres in length, the soil over which the fruits grow usually suffers no direct negative impact from habitat utilisation by the root system of the maternal plant. Additionally, annuality eliminates any direct competition between generations. Moreover, the wild cucumber, as a climbing plant, produces fruits which hang above the ground. In most cases, either these fruits are unavailable to rodents, or access to them is very difficult. This additionally enhances the effectiveness of trapped seed protection. During the winter, the remains of individual plants with fruits, or fruits alone, fall to the ground. If a fruit that falls to the soil surface contains trapped seeds, these seeds are then able to germinate, as shown by the results of the germination experiment. We suppose that the trapped seeds depend on certain conditions essential for the reproductive success and self-replacement of this species in optimal environment patches. However, the trapped seeds are smaller and approximately ten per cent lighter than normal seeds, which may result in vigorous growth in the adult plant.

We suspect that the production of trapped seeds in fruits by wild cucumber individuals is a post-introduction phenotypic shift which can modify seed removal by rodents within the species' invasive range. However, we cannot exclude the possibility of trapped 
seed production in the native range of wild cucumber populations, though we have not found any support for this (Torrey and Gray 1841; Choate 1940; Struik 1965; Silvertown 1985; Flora of North America 2015).

Acknowledgements We thank Janusz Kloskowski and two anonymous reviewers for helpful comments on the manuscript. Due to law requirements in Poland we obtained permission to provide the research on an invasive plant species from The Regional Director for Environmental Protection in Poznań (No. of permission: WPN-II.672.1.2016.AS.3, WPNII.672.3.2016.AS.3). The study was financed from budget resources for science in 2016 as a research Project No. 507.511.56.

Open Access This article is distributed under the terms of the Creative Commons Attribution 4.0 International License (http:// creativecommons.org/licenses/by/4.0/), which permits unrestricted use, distribution, and reproduction in any medium, provided you give appropriate credit to the original author(s) and the source, provide a link to the Creative Commons license, and indicate if changes were made.

\section{References}

Alcántara JM, Rey PJ, Sánchez-Lafuente AM, Valera F (2000) Early effects of rodent post-dispersal seed predation on the outcome of the plant-seed disperser interaction. Oikos 88:362-370. https://doi.org/10.1034/j.1600-0706.2000. 880215.x

Aslan CE, Rejmanek M (2016) Avian use of introduced plants: ornithologist records illuminate interspecific associations and research needs. Ecol Appl 20:1005-1020. https://doi. org/10.1890/08-2128.1

Barclay GF (2015) Anatomy and morphology of seed plants. Wiley, Chichester. https://doi.org/10.1002/ 9780470015902.a0002068.pub2

Blair AC, Wolfe LM (2004) The evolution of an invasive plant: an experimental study with Silene latifolia. Ecology 85:3035-3042. https://doi.org/10.1890/04-0341

Blaney CS, Kotanen PM (2001) Post-dispersal losses to seed predators: an experimental comparison of native and exotic old field plants. Can J Bot 79:284-292. https://doi.org/10. 1139/cjb-79-3-284

Bogdziewicz M, Bonal R, Espelta JM, Kalemba EM, Steele MA, Zwolak R (2017) Invasive oaks escape pre-dispersal insect seed predation and trap enemies in their seeds. Integr Zool. https://doi.org/10.1111/1749-4877.12285

Brancalion PH, Novembre AD, Rodrigues RR, Marcos Filho J (2010) Dormancy as exaptation to protect mimetic seeds against deterioration before dispersal. Ann Bot 105:991-998. https://doi.org/10.1093/aob/mcq068

Callaway RM, Ridenour WM (2004) Novel weapons: invasive success and the evolution of increased competitive ability. Front Ecol Environ 2:436-443. https://doi.org/10.1890/ 1540-9295(2004)002[0436:NWISAT]2.0.CO;2
Carrillo-Gavilán MA, Lalagüe H, Vila M (2010) Comparing seed removal of 16 pine species differing in invasiveness. Biol Invasions 12:2233-2242. https://doi.org/10.1007/ s10530-009-9633-y

Choate HA (1940) Dormancy and germination in seeds of Echinocystis lobata. Am J Bot 27:156-160

Connolly BM, Pearson DE, Mack RN (2014) Granivory of invasive, naturalized, and native plants in communities differentially susceptible to invasion. Ecology 95:1759-1769. https://doi.org/10.1890/13-1774.1

Core Team R (2015) R: a language and environment for statistical computing. R Foundation for Statistical Computing, Vienna

Cox DR (1972) Regression models and life tables. J R Stat Soc 34:187-220

Flora of North America Editorial Committee (2015) Flora of North America: Volume 6: Magnoliophyta: Cucurbitaceae to Droserceae. Oxford University Press, New York

Foster S, Duke JA (1990) A field guide to medicinal plants: eastern and central North America. Houghton Mifflin Company, Boston

Fuller PJ, Hay ME (1983) Is glue production by seeds of Salvia columbariae a deterrent to desert granivores? Ecology 64:960-963. https://doi.org/10.2307/1937217

Grime JP (1979) Plant strategies, vegetation processes, and ecosystem properties. Wiley, Chichester

Guiden PW, Orrock JL (2017) Invasive exotic shrub modifies a classic animal-habitat relationship and alters patterns of vertebrate seed predation. Ecology 98:321-327. https:// doi.org/10.1002/ecy.1678

Harms KE, Wright SJ, Calderon O, Hernandez A, Herre EA (2000) Pervasive density-dependent recruitment enhances seedling diversity in a tropical forest. Nature 404:493-495. https://doi.org/10.1038/35006630

Henery ML, Westoby M (2001) Seed mass and seed nutrient content as predictors of seed output variation between species. Oikos 92:479-490. https://doi.org/10.1034/j. 1600-0706.2001.920309.x

Hulme PE (1996) Herbivory, plant regeneration, and species coexistence. J Ecol 84:609-615. https://doi.org/10.2307/ 2261482

Hulme PE (1998a) Post-dispersal seed predation: consequences for plant demography and evolution. Perspect Plant Ecol Evol Syst 1:32-46. https://doi.org/10.1078/1433-831900050

Hulme PE (1998b) Post-dispersal seed predation and seed bank persistence. Seed Sci Res 8:513-519. https://doi.org/10. 1017/S0960258500004487

Hulme P, Benkman CW (2002) Granivory. In: Herrera C, Pellmyr O (eds) Plant-animal interactions: an evolutionary approach. Blackwell Scientific Publications, New York, pp 132-154

Jakobsson A, Eriksson O (2000) A comparative study of seed number, seed size, seedling size and recruitment in grassland plants. Oikos 88:494-502. https://doi.org/10.1034/j. 1600-0706.2000.880304.x

Janzen DH (1970) Herbivores and the number of tree species in tropical forests. Am Nat 102:592-595. https://doi.org/10. $1086 / 282687$ 
Janzen DH (1971) Seed predation by animals. Annu Rev Ecol Evol Syst 2:465-492. https://doi.org/10.1146/annurev.es. 02.110171 .002341

Jinks R, Mason B (1998) Effects of seedling density on the growth of Corsican pine (Pinus nigra var. maritima Melv.), Scots pine (Pinus sylvestris L.) and Douglas-fir (Pseudotsuga menziesii Franco) in containers. Ann For Sci 55:407-423. https://doi.org/10.1051/forest:19980402

Lambers JHR, Clark JS, Beckage B (2002) Density-dependent mortality and the latitudinal gradient in species diversity. Nature 417:732-735. https://doi.org/10.1038/nature00809

Lambrinos JG (2006) Spatially variable propagule pressure and herbivory influence invasion of chaparral shrubland by an exotic grass. Oecologia 147:327-334. https://doi.org/10. 1007/s00442-005-0259-1

Lev-Yadun S (2016) Defensive (anti-herbivory) coloration in land plants. Springer, Switzerland

Maron JL, Vilà M (2001) When do herbivores affect plant invasion? Evidence for the natural enemies and biotic resistance hypotheses. Oikos 95:361-373. https://doi.org/ 10.1034/j.1600-0706.2001.950301.x

Maron JL, Pearson DE, Potter T, Ortega YK, Rees M (2012) Seed size and provenance mediate the joint effects of disturbance and seed predation on community assembly. J Ecol 100:1492-1500

McNair JN, Sunkara A, Frobish D (2012) How to analyse seed germination data using statistical time-to-event analysis: non-parametric and semi-parametric methods. Seed Sci Res 22:77-95. https://doi.org/10.1017/ S0960258511000547

Müller-Schärer H, Schaffner U, Steinger T (2004) Evolution in invasive plants: implications for biological control. Trends Ecol Evol 19:417-422. https://doi.org/10.1016/j.tree.2004. 05.010

Myczko Ł, Dylewski Ł, Zduniak P, Sparks TH, Tryjanowski P (2014) Predation and dispersal of acorns by European Jay (Garrulus glandarius) differs between a native (Pedunculate Oak Quercus robur) and an introduced oak species (Northern Red Oak Quercus rubra) in Europe. Forest Ecol Manag 331:35-39. https://doi.org/10.1016/j.foreco.2014. 07.027

Myczko Ł, Skórka P, Dylewski Ł, Sparks TH, Tryjanowski P (2015) Color mimicry of empty seeds influences the probability of predation by birds. Ecosphere 6:177. https:// doi.org/10.1890/ES15-00055.1

Myczko Ł, Dylewski Ł, Chrzanowski A, Sparks TH (2017) Acorns of invasive Northern Red Oak (Quercus rubra) in Europe are larval hosts for moths and beetles. Biol Invasions 19:2419-2425. https://doi.org/10.1007/s10530-0171452-y

Nathan RAN, Casagrandi R (2004) A simple mechanistic model of seed dispersal, predation and plant establishment: Janzen-Connell and beyond. J Ecol 92:733-746. https://doi. org/10.1111/j.0022-0477.2004.00914.x

Nentwig W (2009) Handbook of alien species in Europe, vol 3. Springer, New York

Nuñez MA, Simberloff D, Andrea Revla M (2008) Seed predation as a barrier to alien conifer invasions. Biol Invasions 10:1389-1398. https://doi.org/10.1007/s10530-007-9214$\mathrm{x}$
Nystrand O, Granström M (1997) Post-dispersal predation on Pinus sylvestris seeds by Fringilla spp: ground substrate affects selection for seed color. Oecologia 110:353-359. https://doi.org/10.1007/s004420050169

Ortega YK, Greenwood LF, Callaway RM, Pearson DE (2014) Different responses of congeneric consumers to an exotic food resource: who gets the novel resource prize? Biol Invasions 16:1757-1767. https://doi.org/10.1007/s10530013-0625-6

Pearson DE, Callaway RM, Maron JL (2011) Biotic resistance via granivory: establishment by invasive, naturalized, and native asters reflects generalist preference. Ecology 92:1748-1757. https://doi.org/10.1890/11-0164.1

Pearson DE, Potter T, Maron JL (2012) Biotic resistance: exclusion of native rodent consumers releases populations of a weak invader. J Ecol 100:1383-1390. https://doi.org/ 10.1111/j.1365-2745.2012.02025.x

Pearson DE, Hierro JL, Chiuffo M, Villarreal D (2014) Rodent seed predation as a biotic filter influencing exotic plant abundance and distribution. Biol Invasions 16:1185-1196. https://doi.org/10.1007/s10530-013-0573-1

Pearson DE, Ortega YK, Eren Ö, Hierro JL (2018) Community assembly theory as a framework for biological invasions. Trends Ecol Evol 33:313-325. https://doi.org/10.1016/j. tree.2018.03.002

Perea R, Venturas M, Gil L (2013) Empty seeds are not always bad: simultaneous effect of seed emptiness and masting on animal seed predation. PLoS ONE 8:e65573. https://doi. org/10.1371/journal.pone.0065573

Peres CA, Schiesari LC, Dias-Leme CL (1997) Vertebrate predation of Brazil-nuts (Bertholletia excelsa, Lecythidaceae), an agouti-dispersed Amazonian seed crop: a test of the escape hypothesis. J Trop Ecol 13:69-79. https://doi. org/10.1017/S0266467400010269

Perukschas J, Zeiter M, Fischer M, Stampfli A (2014) Biotic resistance to plant invasion in grassland: does seed predation increase with resident plant diversity. Basic Appl Ecol 15:133-141. https://doi.org/10.1016/j.baae.2014.01.004

Porter SS (2013) Adaptive divergence in seed color camouflage in contrasting soil environments. New Phytol 197:1311-1320. https://doi.org/10.1111/nph.12110

Prentis PJ, Wilson JR, Dormontt EE, Richardson DM, Lowe AJ (2008) Adaptive evolution in invasive species. Trends Plant Sci 13:288-294. https://doi.org/10.1016/j.tplants. 2008.03.004

Reader RJ (1993) Control of seedling emergence by ground cover and seed predation in relation to seed size for some old-field species. J Ecol 81:169-175. https://doi.org/10. 2307/2261232

Richards CL, Bossdorf O, Muth NZ, Gurevitch J, Pigliucci M (2006) Jack of all trades, master of some? On the role of phenotypic plasticity in plant invasions. Ecol Lett 9:981-993. https://doi.org/10.1111/j.1461-0248.2006. 00950.x

Schilthuizen M, Pimenta LPS, Lammers Y, Steenbergen PJ, Flohil M, Beveridge NGP, van Duijn PT, Meulblok MM, Sosef N, van de Ven R, Werring R, Beentjes KK, Meijer K, Vos RA, Vrieling K, Gravendeel B, Choi Y, Verpoorte R, Smit C, Beukeboom LW (2016) Incorporation of an invasive plant into a native insect herbivore food web. PeerJ 4:e1954. https://doi.org/10.7717/peerj. 1954 
Schimming T, Jenett-Siems K, Mann P, Tofern-Reblin B, Milson J, Johnson RW, Deroin T, Austin DF, Eich E (2005) Calystegines as chemotaxonomic markers in the Convolvulaceae. Phytochemistry 66:469-480. https://doi.org/ 10.1016/j.phytochem.2004.12.024

Silvertown J (1985) Survival, fecundity and growth of wild cucumber, Echinocystis lobata. J Ecol 73:841-849. https:// doi.org/10.2307/2260151

Šmilauer P, Lepš J (2014) Multivariate analysis of ecological data using CANOCO 5. Cambridge University Press, Cambridge

Struik GJ (1965) Growth patterns of some native annual and perennial herbs in southern Wisconsin. Ecology 46:401-420. https://doi.org/10.2307/1934873

Torrey J, Gray A (1841) A flora of North America: containing abridged descriptions of all the known-indigenous and naturalized plants growing North of Mexico: arranged according to the natural system, vol 2. Wiley \& Putnam, New York

van Klinken RD, White AJ (2014) The role of pre- and postdispersal seed predation in determining total seed loss. Basic Appl Ecol 15:581-589. https://doi.org/10.1016/j. baae.2014.08.012
Vilà M, Gimero I (2003) Seed predation of two alien Opuntia species invading Mediterranean communities. Plant Ecol 167:1-8. https://doi.org/10.1023/A:1023956108731

Xiao Z, Zhang Z, Wang Y (2005) Effects of seed size on dispersal distance in five rodent-dispersed fagaceous species. Acta Oecol 28:221-229. https://doi.org/10.1016/j.actao. 2005.04.006

Yoshida T, Goka K, Ishihama F, Ishihara M, Kudo SI (2007) Biological invasion as a natural experiment of the evolutionary processes: introduction of the special feature. Ecol Res 22:849-854. https://doi.org/10.1007/s11284-0070435-3

Yu F, Shi X, Wang D, Wang T, Yi X, Lou Y (2014) Seed predation patterns favor the regeneration of dominant species in forest gaps compared with the understory in an oak-pine mixed forest. Acta Theriol 59:495-502. https:// doi.org/10.1007/s13364-014-0192-y

Zwolak R, Bogdziewicz M, Rychlik L (2016) Beech masting modifies the response of rodents to forest management. Forest Ecol Manag 359:268-276. https://doi.org/10.1016/j. foreco.2015.10.017 